\title{
Bromatological Analysis from Medicinally Relevant Wild Edible Plant Parts
}

\author{
Mahadkar Shivprasad*1, Valvi Sujata ${ }^{2}$, Jadhav Varsha ${ }^{2}$ \\ ${ }^{1}$ Assistant Professor, Department of Botany Dr. Shantilal Dhanji Devse Arts College, Commerce and \\ Science College, Wada; Palghar \\ ${ }^{2}$ Assistant Professor, Department of Botany, Nowrosjee Wadia College, Pune \\ ${ }^{2}$ Associate Professor, Department of Botany Shivaji University Kolhapur.
}

Email: - mshivprasad007@gmail.com

Abstract: - The wild edible plant parts such as tubers, rhizomes, corm, fruits, inflorescence, leaves, flowers, stems were consumed by rural peoples of Kolhapur district, Maharashtra, India. Ten wild edible plant species viz. Bauhinia recemosa Lam., Caryota urens L, Gmelina arborea Roxb, Oroxylum indicum (L.) Vent, Zanthoxylum rhetsa (Roxb.) DC, Commelina benghalensis L, Garcinia indica (Du Petit-Thou.) Choisy, Smilax zeylanica L, Ensete superbum (Roxb.) Cheesuran, Woodfordia fruticosa (L.) Kurz. from different localities of Kolhapur district was selected for present study. In bromatological analysis leaves of Commelina benghalensis show lower dry matter $(4.44 \pm 1.10 \% \mathrm{FW})$ and crude fat $(0.8 \pm 0.3 \% \mathrm{DW})$ content. Lower crude protein $(1.375 \pm 0.0190 \mathrm{~g} / 100 \mathrm{~g} \mathrm{DW})$ and total ash $(6.24 \pm 0.15 \% \mathrm{DW})$ content was observed in fruits of Bauhinia recemosa. Fruits of Gmelina arborea show higher moisture $(94.2 \pm 1.25$ $\% \mathrm{FW}$ ) and total ash $(18.16 \pm 0.10 \% \mathrm{DW})$ but higher dry matter $(37.9 \pm \pm 0.50 \% \mathrm{FW})$ and lower moisture $(62.1 \pm 0.50 \% \mathrm{FW})$ was observed in fruits of Caryota urens. Fruits of Zanthoxylum rhetsa consist of higher crude fat $(3.8 \pm 0.45 \% \mathrm{DW})$, crude protein $(4.518 \pm 0.0184 \mathrm{~g} / 100 \mathrm{~g} \mathrm{DW})$ and lower crude fiber $(6.23 \pm 0.55 \% \mathrm{DW})$ content. Crude fiber $(12.79 \pm 2.52 \% \mathrm{DW})$ is higher in flowers of Ensete Superbum. In case of carbohydrate analysis highest reducing sugars, total sugars and energy was observed in flowers of Woodfordia fruticosa $(0.4131 \pm 0.0058 \mathrm{~g} / 100 \mathrm{~g} \mathrm{DW}, 0.8122 \pm 0.0071 \mathrm{~g} / 100 \mathrm{~g} \mathrm{DW}, 48.4851 \pm 0.4893 \mathrm{kcal} / 100 \mathrm{~g}$ $\mathrm{DW})$ and lowest in flowers of Ensete Superbum $(0.0775 \pm 0.0052 \mathrm{~g} / 100 \mathrm{~g} \mathrm{DW}, 0.1035 \pm 0.0129 \mathrm{~g} / 100 \mathrm{~g} \mathrm{DW}$, $18.3683 \pm 0.2240 \mathrm{kcal} / 100 \mathrm{~g} \mathrm{DW})$, highest starch content was observed in flowers of Woodfordia fruticosa $(2.0808 \pm 0.0327 \mathrm{~g} / 100 \mathrm{~g} \mathrm{DW})$ and lowest in fruits of Caryota urens $(0.8772 \pm 0.0155 \mathrm{~g} / 100 \mathrm{~g} \mathrm{DW})$.

Keyword: Neutracutical analysis, Bromatological analysis, proximate composition, wild edible plant, Kolhapur district.

\section{Introduction}

Wild plants make an important contribution to the life of rural communities. Wild edible plants are those with one or more parts that can be used for food, if gathered at the appropriate stage of growth and properly prepared. Rural people fulfil their nutritional requirement from wild resources. They got knowledge of wild edible plants traditionally. This traditional knowledge is useful to develop new food sources.
At least one billion people can analyse the nutrients for preliminary assessment are thought to use wild foods in their diet. In India, Malaysia and Thailand, about 150 wild plant species have been identified as sources of emergency food (Burlingame, 2000). Bromatological analysis of edible fruit and vegetables plays a crucial role in assessing their nutritional significance (Pandey et al., 2006). The considerable use of wild edible species by the local people in their diet motivated 
us to carry out the present bromatological analysis.

\section{Materials and Methods}

\section{Material:}

The bromatological analysis was conducted for the parts of ten wild edible plant species such as
Bauhinia recemosa Lam., Caryota urens L, Gmelina arborea Roxb, Oroxylum indicum (L.) Vent, Zanthoxylum rhetsa (Roxb.) DC, Commelina benghalensis L, Garcinia indica (Du Petit-Thou.) Choisy, Smilax zeylanica L, Ensete superbum (Roxb.) Cheesuran, Woodfordia fruticosa (L.) Kurz.

\section{Table 1. Bromatological analysis of ten wild edible plants.}

\begin{tabular}{|c|c|c|c|c|c|c|c|c|c|}
\hline $\begin{array}{l}\text { Sr. } \\
\text { No. }\end{array}$ & $\begin{array}{c}\text { Name of Plant } \\
\text { species }\end{array}$ & Family & $\begin{array}{c}\text { Vernacular } \\
\text { Name }\end{array}$ & $\begin{array}{c}\text { Edible } \\
\text { plant } \\
\text { part }\end{array}$ & $\begin{array}{c}\text { Non reducing } \\
\text { sugars } \\
\text { (g/100g of } \\
\text { DW) }\end{array}$ & $\begin{array}{l}\text { Reducing } \\
\text { Sugars } \\
\text { (g/100g of } \\
\text { DW) }\end{array}$ & $\begin{array}{c}\text { Total } \\
\text { Sugars } \\
\text { (g/100g of } \\
\text { DW) }\end{array}$ & $\begin{array}{l}\begin{array}{c}\text { Starch } \\
(\mathrm{g} / 100 \mathrm{~g} \text { of }\end{array} \\
\text { DW) }\end{array}$ & $\begin{array}{l}\text { Total } \\
\text { Carbohydrate } \\
\text { (g/100g of DW) }\end{array}$ \\
\hline 1. & $\begin{array}{l}\text { Ensete Superbum } \\
\text { (Roxb.) } \\
\text { Cheesuran }\end{array}$ & Musaceae & $\begin{array}{c}\text { Ran-keli, } \\
\text { Chaveli- } \\
\text { keli }\end{array}$ & Flower & $\begin{array}{r}\mathbf{0 . 0 2 3 4} \\
\pm 0.0116\end{array}$ & $\begin{array}{r}\mathbf{0 . 0 7 7 5} \\
\pm 0.0052\end{array}$ & $\begin{array}{r}\mathbf{0 . 1 0 3 5} \\
\pm 0.0129\end{array}$ & $\begin{array}{c}1.006 \\
\pm 0.020\end{array}$ & $\begin{array}{c}1.0999 \\
\pm 0.01379\end{array}$ \\
\hline 2. & $\begin{array}{l}\text { Gmelina arborea } \\
\text { Roxb }\end{array}$ & Verbenaceae & Shivan & Fruit & $\begin{array}{c}\mathbf{0 . 0 5 3} \\
\pm 0.0127\end{array}$ & $\begin{array}{c}\mathbf{0 . 2 0 4 1} \\
\pm 0.0180\end{array}$ & $\begin{array}{r}\mathbf{0 . 2 5 7 2} \\
\pm 0.0064\end{array}$ & $\begin{array}{c}\mathbf{0 . 9 6 9 0} \\
\pm 0.0158\end{array}$ & $\begin{array}{r}1.2335 \\
\pm 0.0190\end{array}$ \\
\hline 3. & $\begin{array}{l}\text { Oroxylum indicum } \\
\text { (L.) Vent, }\end{array}$ & Bignoniaceae & Tetu & Fruit & $\begin{array}{r}\mathbf{0 . 0 5 5 6} \\
\pm 0.0011\end{array}$ & $\begin{array}{r}\mathbf{0 . 1 5 8 8} \\
\pm 0.0041\end{array}$ & $\begin{array}{r}\mathbf{0 . 2 1 0 2} \\
\pm 0.0067\end{array}$ & $\begin{array}{c}\mathbf{0 . 9 5 7 6} \\
\pm 0.0158\end{array}$ & $\begin{array}{c}\mathbf{1 . 1 7 6 6} \\
\pm 0.0120\end{array}$ \\
\hline 4. & $\begin{array}{l}\text { Bauhinia recemosa } \\
\text { Lam. }\end{array}$ & Caesalpiniaceae & Apata & Fruit & $\begin{array}{r}\mathbf{0 . 0 1 6 1} \\
\pm 0.0011\end{array}$ & $\begin{array}{r}\mathbf{0 . 2 0 3 0} \\
\pm 0.0035\end{array}$ & $\begin{array}{r}\mathbf{0 . 2 1 9 3} \\
\pm 0.0041\end{array}$ & $\begin{array}{r}\mathbf{1 . 1 0 4 5} \\
\pm 0.0522\end{array}$ & $\begin{array}{r}\mathbf{1 . 3 2 3 8} \\
\pm 0.0549\end{array}$ \\
\hline 5. & Caryota urens $\mathrm{L}$ & Arecaceae & Ardhashishi & Fruit & $\begin{array}{c}\mathbf{0 . 1 0 7 2} \\
\pm 0.0032\end{array}$ & $\begin{array}{r}\mathbf{0 . 1 8 7 2} \\
\pm 0.0071\end{array}$ & $\begin{array}{r}\mathbf{0 . 2 9 4 4} \\
\pm 0.0038\end{array}$ & $\begin{array}{c}\mathbf{0 . 8 7 7 2} \\
\pm 0.0155\end{array}$ & $\begin{array}{r}\mathbf{1 . 1 7 1 6} \\
\pm 0.01180\end{array}$ \\
\hline 6. & Smilax zeylanica $\mathrm{L}$ & Smilacaceae & Chopchini & Leaves & $\begin{array}{c}\mathbf{0 . 0 5 6 4} \\
\pm 0.0076\end{array}$ & $\begin{array}{r}\mathbf{0 . 2 2 5 6} \\
\pm 0.0012\end{array}$ & $\begin{array}{r}\mathbf{0 . 2 8 2 0} \\
\pm 0.0064\end{array}$ & $\begin{array}{l}\mathbf{0 . 9 7 4 1} \\
\pm 0.0145\end{array}$ & $\begin{array}{r}1.2561 \\
\pm 0.0083\end{array}$ \\
\hline 7. & $\begin{array}{l}\text { Woodfordia } \\
\text { fruticosa }(\mathrm{L} .) \\
\text { Kurz }\end{array}$ & Lytharaceae & Dhayati & Flower & $\begin{array}{r}\mathbf{0 . 4 0 2 7} \\
\pm 0.0131\end{array}$ & $\begin{array}{c}\mathbf{0 . 4 1 3 1} \\
\pm 0.0058\end{array}$ & $\begin{array}{r}\mathbf{0 . 8 1 2 2} \\
\pm 0.0071\end{array}$ & $\begin{array}{r}\mathbf{2 . 0 8 0 8} \\
\pm 0.0327\end{array}$ & $\begin{array}{l}\mathbf{2 . 9 0 3 3} \\
\pm 0.0293\end{array}$ \\
\hline 8. & $\begin{array}{l}\text { Commelina } \\
\text { benghalensis } \mathrm{L} .\end{array}$ & Commelinaceae & Kena & Leaves & $\begin{array}{c}\mathbf{0 . 0 1 6 7} \\
\pm 0.0081\end{array}$ & $\begin{array}{c}\mathbf{0 . 1 9 3 9} \\
\pm 0.0032\end{array}$ & $\begin{array}{r}\mathbf{0 . 2 0 8 2} \\
\pm 0.0047\end{array}$ & $\begin{array}{r}1.1040 \\
\pm 0.0183\end{array}$ & $\begin{array}{r}1.3122 \\
\pm 0.0224\end{array}$ \\
\hline 9. & $\begin{array}{l}\text { Garcinia indica } \\
\text { (Du Petit- } \\
\text { Thou.) Choisy }\end{array}$ & Clusiaceae & Kokam & Leaves & $\begin{array}{c}\mathbf{0 . 0 4 2 3} \\
\pm 0.0093\end{array}$ & $\begin{array}{r}\mathbf{0 . 1 6 3 4} \\
\pm 0.0061\end{array}$ & $\begin{array}{r}\mathbf{0 . 2 0 0 2} \\
\pm 0.0053\end{array}$ & $\begin{array}{c}1.006 \\
\pm 0.0211\end{array}$ & $\begin{array}{c}1.1932 \\
\pm 0.02100\end{array}$ \\
\hline 10. & $\begin{array}{l}\text { Zanthoxylum } \\
\text { rhetsa (Roxb.) } \\
\text { DC }\end{array}$ & Rutaceae & $\begin{array}{l}\text { Tirphal, } \\
\text { Chirphal. }\end{array}$ & Fruit & $\begin{array}{r}\mathbf{0 . 0 5 5 8} \\
\pm 0.0074 \\
\end{array}$ & $\begin{array}{r}\mathbf{0 . 1 8 3 6} \\
\pm 0.0025\end{array}$ & $\begin{array}{r}\mathbf{0 . 2 3 7 5} \\
\pm 0.0061 \\
\end{array}$ & $\begin{array}{c}1.000 \\
\pm 0.0057\end{array}$ & $\begin{array}{r}1.2580 \\
\pm 0.0009 \\
\end{array}$ \\
\hline
\end{tabular}


Table 2. Bromatological analysis of ten wild edible plants.

\begin{tabular}{|c|c|c|c|c|c|c|c|c|}
\hline Sr. No. & Name of Plant species & Family & Vernacular Name & $\begin{array}{c}\text { Edible } \\
\text { plant } \\
\text { part }\end{array}$ & $\begin{array}{r}\text { Energy } \\
\text { (kcal/100g } \\
\text { of DW) }\end{array}$ & \begin{tabular}{|} 
Crude protein \\
(g/100g of \\
DW)
\end{tabular} & $\begin{array}{c}\text { Moisture } \\
\text { (\% in fresh } \\
\text { wt.) }\end{array}$ & $\begin{array}{l}\text { Dry matter } \\
\text { (\% in fresh } \\
\text { wt.) }\end{array}$ \\
\hline 1. & $\begin{array}{l}\text { Ensete Superbum (Roxb.) } \\
\text { Cheesuran }\end{array}$ & Musaceae & Ran-keli, Chaveli-keli & Flower & $\begin{array}{r}18.3683 \\
\pm 0.2240\end{array}$ & $\begin{array}{r}\mathbf{2 . 0 6 2 5} \\
\pm 0.0252\end{array}$ & $\begin{array}{r}92.8 \\
\pm 1.10\end{array}$ & $\begin{array}{r}7.2 \\
\pm 1.10\end{array}$ \\
\hline 2. & Gmelina arborea Roxb & Verbenaceae & Shivan & Fruit & $\begin{array}{r}\mathbf{2 0 . 5 9 9 9} \\
\pm 0.3179\end{array}$ & $\begin{array}{r}\mathbf{2 . 4 3 7 5} \\
\pm 0.0250\end{array}$ & $\begin{array}{r}94.2 \\
\pm 1.25\end{array}$ & $\begin{array}{r}\mathbf{5 . 8} \\
\pm 1.25\end{array}$ \\
\hline 3. & Oroxylum indicum (L.) Vent, & Bignoniaceae & Tetu & Fruit & $\begin{array}{l}19.6492 \\
\pm 0.2017\end{array}$ & $\begin{array}{r}4.1612 \\
\pm 0.0259\end{array}$ & $\begin{array}{r}77.9 \\
\pm 0.92\end{array}$ & $\begin{array}{r}22.1 \\
\pm 0.92\end{array}$ \\
\hline 4. & Bauhinia recemosa Lam. & Caesalpiniaceae & Apata & Fruit & $\begin{array}{r}22.1074 \\
\pm 0.9179\end{array}$ & $\begin{array}{r}1.375 \\
\pm 0.0190\end{array}$ & $\begin{array}{r}76.3 \\
\pm 1.09\end{array}$ & $\begin{array}{r}23.7 \\
\pm 1.09\end{array}$ \\
\hline 5. & Caryota urens $\mathrm{L}$ & Arecaceae & Ardhashishi, & Fruit & $\begin{array}{r}\mathbf{1 9 . 5 6 5 7} \\
\pm 0.1971\end{array}$ & $\begin{array}{r}3.125 \\
\pm 0.0280\end{array}$ & $\begin{array}{r}62.1 \\
\pm 0.50\end{array}$ & $\begin{array}{r}37.9 \\
\pm 0.50\end{array}$ \\
\hline 6. & Smilax zeylanica $\mathrm{L}$ & Smilacaceae & Chopchini & Leaves & $\begin{array}{r}\mathbf{2 0 . 9 7 6 8} \\
\pm 0.6996\end{array}$ & $\begin{array}{r}\mathbf{3 . 8 5 0} \\
\pm 0.0344\end{array}$ & $\begin{array}{r}87 \\
\pm 0.45\end{array}$ & $\begin{array}{c}13 \\
\pm 0.45\end{array}$ \\
\hline 7. & Woodfordia fruticosa (L.) Kurz & Lytharaceae & Dhayati & Flower & $\begin{array}{l}\mathbf{4 8 . 4 8 5 1} \\
\pm 0.4893\end{array}$ & $\begin{array}{c}1.75 \\
\pm 0.0315\end{array}$ & $\begin{array}{r}90.6 \\
\pm 0.94\end{array}$ & $\begin{array}{r}9.4 \\
\pm 0.94\end{array}$ \\
\hline 8. & Commelina benghalensis $\mathrm{L}$ & Commelinaceae & Kena & Leaves & $\begin{array}{l}\mathbf{2 1 . 9 1 3 7} \\
\pm 0.3755\end{array}$ & $\begin{array}{r}3.125 \\
\pm 0.0312\end{array}$ & $\begin{array}{l}95.56 \\
\pm 1.10\end{array}$ & $\begin{array}{r}4.44 \\
\pm 1.10\end{array}$ \\
\hline 9. & $\begin{array}{l}\text { Garcinia indica (Du Petit- } \\
\text { Thou.) Choisy }\end{array}$ & Clusiaceae & Kokam & Leaves & $\begin{array}{r}19.9264 \\
\pm 0.3508\end{array}$ & $\begin{array}{c}3.5 \\
\pm 0.040\end{array}$ & $\begin{array}{r}75.03 \\
\pm 0.27\end{array}$ & $\begin{array}{l}\mathbf{2 4 . 9 7} \\
\pm 0.40\end{array}$ \\
\hline 10. & Zanthoxylum rhetsa (Roxb.) DC & Rutaceae & Tirphal, Chirphal. & Fruit & $\begin{array}{r}\mathbf{2 0 . 6 7 4 0} \\
\pm 0.01651\end{array}$ & $\begin{array}{r}4.518 \\
\pm 0.0184\end{array}$ & $\begin{array}{r}89.4 \\
\pm 1.37\end{array}$ & $\begin{array}{r}\mathbf{1 0 . 6} \\
\pm 1.37\end{array}$ \\
\hline
\end{tabular}


Table 3. Bromatological analysis of ten wild edible plants.

\begin{tabular}{|c|c|c|c|c|c|c|c|}
\hline Sr. No. & Name of Plant species & Family & Vernacular Name & $\begin{array}{c}\text { Edible } \\
\text { plant part }\end{array}$ & $\begin{array}{l}\text { Crude fat } \\
\text { (\% in DW) }\end{array}$ & $\begin{array}{l}\text { Crude fiber } \\
(\% \text { in DW) }\end{array}$ & $\begin{array}{l}\text { Total ash } \\
(\% \text { in DW) }\end{array}$ \\
\hline 1. & $\begin{array}{l}\text { Ensete Superbum (Roxb.) } \\
\text { Cheesuran }\end{array}$ & Musaceae & Ran-keli, Chaveli-keli & Flower & $\begin{array}{c}3 \\
\pm 0.3\end{array}$ & $\begin{array}{r}\mathbf{1 2 . 7 9} \\
\pm 2.52\end{array}$ & $\begin{array}{l}\mathbf{1 0 . 3 7} \\
\pm 0.07\end{array}$ \\
\hline 2. & Gmelina arborea Roxb & Verbenaceae & Shivan & Fruit & $\begin{array}{c}1 \\
\pm 0.25\end{array}$ & $\begin{array}{r}7.68 \\
\pm 0.40\end{array}$ & $\begin{array}{l}18.16 \\
\pm 0.10\end{array}$ \\
\hline 3. & Oroxylum indicum $(\mathrm{L}$.$) Vent,$ & Bignoniaceae & Tetu & Fruit & $\begin{array}{c}2.3 \\
\pm 0.50\end{array}$ & $\begin{array}{r}8.84 \\
\pm 0.67\end{array}$ & $\begin{array}{r}9.40 \\
\pm 0.10\end{array}$ \\
\hline 4. & Bauhinia recemosa Lam. & Caesalpiniaceae & Apata & Fruit & $\begin{array}{c}\mathbf{0 . 9} \\
\pm 0.25\end{array}$ & $\begin{array}{r}7.69 \\
\pm 0.50\end{array}$ & $\begin{array}{r}\mathbf{6 . 2 4} \\
\pm 0.15\end{array}$ \\
\hline 5. & Caryota urens $\mathrm{L}$ & Areceae & Ardhashishi, & Fruit & $\begin{array}{c}1.5 \\
\pm 0.25\end{array}$ & $\begin{array}{r}7.93 \\
\pm 0.25\end{array}$ & $\begin{array}{r}10.39 \\
\pm 0.14\end{array}$ \\
\hline 6. & Smilax zeylanica $\mathrm{L}$ & Smilacaceae & Chopchini & Leaves & $\begin{array}{c}\mathbf{2 . 8} \\
\pm 0.3\end{array}$ & $\begin{array}{r}7.16 \\
\pm 0.66\end{array}$ & $\begin{array}{r}\mathbf{5 . 9 0} \\
\pm 0.07\end{array}$ \\
\hline 7. & Woodfordia fruticosa (L.) Kurz & Lytharaceae & Dhayati & Flower & $\begin{array}{c}2.3 \\
\pm 0.45\end{array}$ & $\begin{array}{r}7.31 \\
\pm 0.85\end{array}$ & $\begin{array}{r}8.17 \\
\pm 0.09\end{array}$ \\
\hline 8. & Commelina benghalensis $\mathrm{L}$ & Commelinaceae & Kena & Leaves & $\begin{array}{c}\mathbf{0 . 8} \\
\pm 0.3\end{array}$ & $\begin{array}{c}10 \\
\pm 0.69\end{array}$ & $\begin{array}{r}8.37 \\
\pm 0.08\end{array}$ \\
\hline 9. & $\begin{array}{l}\text { Garcinia indica (Du Petit- } \\
\text { Thou.) Choisy }\end{array}$ & Clusiaceae & Kokam & Leaves & $\begin{array}{r}1.5 \\
\pm 0.35\end{array}$ & $\begin{array}{r}7.71 \\
\pm 0.59\end{array}$ & $\begin{array}{l}\mathbf{1 0 . 3 0} \\
\pm 0.04\end{array}$ \\
\hline 10. & Zanthoxylum rhetsa (Roxb.) DC & Rutaceae & Tirphal, Chirphal. & Fruit & $\begin{array}{c}3.8 \\
\pm 0.45\end{array}$ & $\begin{array}{r}6.23 \\
\pm 0.55\end{array}$ & $\begin{array}{r}6.37 \\
\pm 0.16\end{array}$ \\
\hline
\end{tabular}

\section{Collection of Plant material:}

The collection of wild edible plant parts from various localities of Kolhapur district were done during flowering and fruiting period of each plant. Collected plant material was placed in a polythene bag to prevent loss of moisture during transportation to the laboratory. The standard floras were used for correct identification of plant species.

\section{Sample preparation:}

The healthy and fresh plant parts were washed thoroughly to remove external dust. They were blotted till the excess moisture get absorbed, air dried and weighted to obtain fresh weight. Plant parts were cut in to small pieces and placed in envelops of blotting paper and dried in the oven at 400C until constant weight was obtained. After complete drying the sample was ground to a fine powder by using an electric grinder. The plant powder was packed into airtight sample bottles. 


\section{Methods:}

Dry matter, moisture and ash was carried out by using the method of AOAC (1990). Crude fiber, crud fat was described by Sadasivam and Manikam (1992). Crude protein estimated by Hawk et al. (1948). Carbohydrates were estimated by Anthron method (Nelson, 1944) and the Atwater system was used to determine the energy values.

\section{Results and Discussion}

In these experiments moisture, dry matter, crude protein, crude fibre, crude fat, total ash, reducing sugar, total sugar, starch and energy content of the wild edible plant parts were analysed. The results are shown in respective tables.

Varma and Khosa (2009) carried out pharmacognostical studies on Zanthoxylum armatum leaves. They analysed parameters like total ash, acid soluble ash, water soluble ash, moisture content, water content, foreign organic matter, water soluble extractive, alcohol soluble extractive, chloroform soluble extractive, petroleum ether soluble extractive etc. Moisture content in leaves of $Z$. armatum is $8.97 \%$. Goodson (1921) evaluated constituents of the bark of Zanthoxylum macrophyllum. They mentioned bark of Z. macrophyllum contains $11.2 \%$ of moisture and $4.7 \%$ ash. In present study moisture content $(89.1 \pm 1.37 \% \mathrm{FW} \mathrm{Z}$. rhetsa fruits) is reported to be higher. Earlier authors used as bark and leaves for their study. In present work fruits had been taken.

Dev et al. (2010) carried out Pharmacognostic and phytochemical studies of bark of Oroxylum indicum. They carried out preliminary phytochemical studies of bark of Oroxylum indicum including morphological, microscopical, physiochemical studies along with phytochemical studies. In physiochemical properties of stem bark of Oroxylum indicum they obtained total ash value $11.767 \pm 0.232 \%$, moisture content $13.845 \pm 0.737 \%$ respectively. In present work, the moisture content $(78.16 \pm 0.92 \%$ O. indicum fruits) is higher than previous work. This difference observed in moisture content because previous author was used stem bark instead of fruits. Bhattacharya and Zaman (2009) worked on pharmacognostical evaluation of Zanthoxylum nitidium bark. They studied microscopic characters, physio-chemical evaluations, phytochemical screening, Thin layer chromatography and fluorescence analysis of stem bark of Z. nitidium. They obtained $5.81 \pm 0.11 \%$ total ash value from stem bark of Z . nitidium. In present study total ash value $(6.57 \pm 0.16 \% \mathrm{Z}$. rhetsa fruits) is same as reported by above author. Plant parts taken for study are different.

Seal (2011) determined nutritive value, mineral contents and antioxidant activity of some wild edible plants from Meghalaya State, India. They evaluated parameters like ash, moisture, crude fat, crude fiber, crude protein, total carbohydrate, nutritive value, mineral content $(\mathrm{Na}, \mathrm{K}, \mathrm{Ca}, \mathrm{Mn}$, $\mathrm{Cu}, \mathrm{Fe}, \mathrm{Cr}, \mathrm{Zn}$ ), total phenolic content and DPPH free radical scavenging activity from selected wild edible plant parts; Zanthoxylum acanthopodium is one of them. In leaves of Z. acanthopodium they reported $7.2 \pm 0.24 \%$ ash, $56.88 \pm 2.67 \%$ moisture, $1.99 \pm 0.08 \%$ crude fat, $28.06 \pm 0.14 \%$ protein, $5.86 \pm 2.53$ total carbohydrate, $5.73 \pm 0.49 \%$ crude fiber, $1536.25 \pm 103.49 \mathrm{kcal} / \mathrm{kg}$ nutritive value, $1.95 \mathrm{mg} / \mathrm{g}$ nitrogen, $33.70 \mathrm{mg} / \mathrm{g}$ potassium, 14.35 $\mathrm{mg} / \mathrm{g}$ calcium, $0.50 \mathrm{mg} / \mathrm{g}$ manganese, $0.012 \mathrm{mg} / \mathrm{g}$ copper, $1.175 \mathrm{mg} / \mathrm{g}$ iron, $0.867 \mathrm{mg} / \mathrm{g}$ zinc, $61.19 \pm 3.01 \mathrm{GAE} \mathrm{mg} / \mathrm{g}$ DM total phenolic content, $240.44 \pm 5.92$ IC50 $\mu \mathrm{g}$ DM/ml DPPH free radical scavenging antioxidant activity. In present study fruits of Z. rhetsa showed $2.11 \pm 0.24 \%$ crude fiber content. Fruits of Z. rhetsa showed lower amount of crude fiber content.

Oselebe et al. (2013) carried out ethnobotanical survey of underutilized crops and spices of some 
local communities in Nigeria: Potentials for improved nutrition, food security and poverty reduction. They documented total 27 traditional leafy vegetables and five spices belonging to 23 families. They selected 3 traditional leafy vegetables for proximate analysis and physiochemical analysis; Zanthoxylum zanthoxyloides is one of them. In leaves of Zanthoxylum zanthoxyloides they obtained $9.6 \%$ moisture, $8.10 \%$ ash, $8.74 \%$ crude protein, $2.1 \%$ crude fat and $21.3 \mathrm{kcal} / 100 \mathrm{~g}$ energy content. In present work fruits of Zanthoxylum rhetsa showed $3.76 \pm 0.45 \%$ crude fat and $20.67 \pm 0.016 \mathrm{~kJ} / 100 \mathrm{~g}$ DW energy content. The values of crude fat and energy are higher in present study. Values obtained in both work is varied may be due to different species have been used.

Nnamani et al. (2009) have done assessment of nutritional values of three underutilized indigenous leafy vegetables of Ebonyi State, Nigeria. They selected three leafy vegetables for their nutritional study; Z. zanthoyloides is one of them. They determined proximate and mineral content from it. In leaves of $\mathrm{Z}$. zanthoyloides they observed protein content was $6.12 \%$. In present study Z. rhetsa fruit showed $4.49 \pm 0.018 \%$ crude protein content. The protein values are lower in present work.

Jin et al. (1999) carried out ethnobotanical studies on wild edible fruits in Southern Yunnan; Folk names; Nutritional values and uses. They collected ethnobotanical information of 123 plant species belonging to 52 families and 82 genera with wild edible fruits used by inhabitants in Southern Yunnan have been recorded. They also evaluated nutritional composition (moisture, total sugars, titratable acid, vitamin ' $\mathrm{C}$ ', soluble tannin, crude fiber, starch, crude fat) of 52 wild edible fruits. They obtained highest starch content in fruits of Sterculia brevissima (16.05\%) and lowest in Citrus macroptera $(0.10 \%)$. In present study fruits O. indicum contain $0.9626 \pm 0.0158 \mathrm{~g} / 100 \mathrm{~g}$
DW starch. Action of proline on stomata differs from that of abscisic acid, G-substances or methyl jasmonate carried out by Raghavendra and Reddy (1987). They obtained reducing sugars $87.2 \mathrm{pmol}$ sucrose $/ \mathrm{mm}-2$, total sugars $116.0 \mathrm{pmol} / \mathrm{mm}-2$, starch $247.2 \mathrm{pmol} / \mathrm{mm}-2$. In present study, leaves of C. benghalensis showed $0.1909 \pm 0.0032 \mathrm{~g} / 100 \mathrm{~g}$ D.W. reducing sugars, $0.2097 \pm 0.0047 \mathrm{~g} / 100 \mathrm{~g}$ Mandal (1997) studied nutritive values of tree leaves of some tropical species for goats. He collected leaves of 31 tropical plant species used for feeding goats for their study; Bauhinia varigata is one of them. The proximate and mineral values obtained from leaves were 10.7-15.9\% DM crude protein, 25.3-33.0\% DM crude fat, 6.3- $12.3 \%$ DM total ash, 1.8-4.1\% DM calcium, $0.2-04 \%$ DM phosphorus, 32.48\% DM starch respectively. In present study fruits of Bauhinia recemosa showed non-reducing sugars content $0.0158 \pm 0.0011 \mathrm{~g} / 100 \mathrm{~g}$ DW, reducing sugars $0.2035 \pm 0.0035 \mathrm{~g} / 100 \mathrm{~g} \mathrm{DW}$, total sugars $0.2193 \pm 0.0041 \mathrm{~g} / 100 \mathrm{~g}$ DW, starch $1.0976 \pm 0.0522$ $\mathrm{g} / 100 \mathrm{~g}$ DW, total carbohydrate $1.3159 \pm 0.0549$ $\mathrm{g} / 100 \mathrm{~g}$ DW, energy $21.9766 \pm 0.9179 \mathrm{~kJ} / 100 \mathrm{~g}$ DW and crude protein $1.37 \pm 0.01 \mathrm{~g} / 100 \mathrm{~g}$ DW. The total sugars, reducing sugars, non reducing sugars, starch, total carbohydrates, energy and crude protein content is higher in previous study as compared to present study. Values obtained in both works is varied may be due to two different species have been used.

Yang et al. (2006) evaluated $203 \mathrm{~g} / \mathrm{kg}$ dry matter content from shoot of $\mathrm{O}$. indicum they obtained. The result of present work shows lower amount $(21.83 \pm 0.92 \% \mathrm{FW})$ of dry matter content in fruits of O. indicum. Annongu and Folorunso (2003) worked on biochemical evaluation of Gmelina arborea fruit meal as a swine feedstuff. They analyzed proximate composition of raw Gmelina arborea fruit meal (Raw GAF meal) and treated Gmelina arborea fruit meal (treated GAF meal). They obtained dry matter content $78.10 \pm 1.30 \%$ and $83.31 \pm 0.40 \%$ from raw GAF meal and treated 
GAF meal respectively, crude protein content $17.56 \pm 0.33 \%$ and $18.41 \pm 0.43 \%$ from raw GAF meal and treated GAF meal respectively, crude fiber content $68.18 \pm 0.41 \%$ and $69.88 \pm 0.47 \%$ from raw GAF meal and treated GAF meal respectively, ash content $3.63 \pm 0.07 \%$ and $10.68 \pm 0.05 \%$ from raw GAF meal and treated GAF meal respectively. The result of present work (fruits of G. arborea) shows $5.9 \pm 1.25 \% \mathrm{FW}$ dry matter. Difference was observed in dry matter content in both works because in present work candidate has taken fresh fruits of G. arborea and previous authors have taken raw and treated fruit meal of G. arborea.

\section{Summary and Conclusion:}

In the bromatological analysis, leaves of Commelina benghalensis and Garcinia indica contains higher amount of moisture and dry matter content respectively. Flowers of Ensete superbum and fruits of Gmelina arborea showed higher amount of crude fiber and total ash contents. Higher amount of crude protein and crude fat present in fruits of Zanthoxylum rhetsa. Reducing sugars, total sugars, starch and energy content were higher in flowers of Woodfordia fruticosa.

In nutritional analysis of selected wild edible plants reveals that moisture, ash, carbohydrates, protein, fat, fiber and energy truth with the RDA levels. The nutritional composition of plants proves that these neglected plants can be a valuable source of nutrients under famine condition.

\section{References:}

1. AOAC. (1990): Official Methods of Analysis. Association of Official Analytical Chemists, Washington. DC.

2. Bhattacharya, S. and Zaman, M. K. (2009). Pharmacognostical evaluation of
Zanthoxylum nitidum bark. Int. J. Pharm. Tech. Res. 1(2): 292-298.

3. Burlingame, B. (2000). Comparison of total lipids, fatty acids, sugars and nonvolatile organic acids in nuts from Castanea species. J. Food Comp. Analysis. 13: 99-100.

4. Dev, L. R., Ranjeeta, P., Anurag, M. and Rajiv, G. (2010). Pharmacognostic and Phytochemical Studies of Bark of Oroxylum indicum. Pharmacognosy J. 2(9): 297-303.

5. Goodson, J. A. (1921). Constituents of the Bark of Zanthoxylum macrophyllum, Oliver. Biochemical J. 15(1): 123-128.

6. Hawk, P. B., Oser, B. L. and Summerson, W. H. (1948). Practical physiological chemistry (Publ.). The Blockiston Co. USA.

7. Jin, C., Yin-Chun, S., Gui-Qin, C. and Wen-Dun, W. (1999). Ethnobotanical studies on wild edible fruits in southern Yunnan: Folk names, nutritional value and uses. Economic Botany. 53(1): 2-14.

8. Mandal, L. (1997). Nutritive values of tree leaves of some tropical species for goats. Small Ruminant Res. 24(2): 95-105.

9. Nelson, N. (1944). A Photochemical adaptation of the Somogyi method for the determination of glucose. J. Biol. Chem. 153: 375-380.

10. Nnamani, C. V., Oselebe, H. O. and Agbatutu, A. (2009). Assessment of nutritional values of three underutilized indigenous leafy vegetables of Ebonyi State, Nigeria. African J. Biotech. 8(9): 2321-2324.

11. Oselebe, H. O., Nnamani, C. V. and Okporie, E. O. (2013). Ethnobotanical Survey of Underutilized Crops and Spices of Some Local Communities in Nigeria: Potentials for Improved Nutrition, Food 
Security and Poverty Reduction. Iosr J. Pharmacy. 3(1): 21-28.

12. Pandey, M., Abidi, A. B., Singh, S., Singh, R. P. (2006). Nutritional Evaluation of Leafy Vegetable Paratha. J. Hum. Ecol. 19 (2): 155-156.

13. Raghavendra, A. S. and Reddy, K. B. (1987). Action of proline on stomata differs from that of abscisic acid, Gsubstances, or methyl jasmonate. Plant physiology. 83(4): 732-734.

14. Sadashivam, S. and Manikam, A. (1992). Biochemical method for agricultural sciences, Willey, Eastern Ltd.: 105.
15. Seal, T. (2011). Determination of nutritive value, mineral contents and antioxidant activity of some wild edible plants from Meghalaya State, India. Asian J. Applied Sci. 4(3): 238-246.

16. Verma, N. and Khosa, R. L. (2009). Pharmacognostical studies on Zanthoxylum armatum leaves. Ancient Science of Life. 29(1): 6-11.

17. Yang, R. Y., Tsou, S., Lee, T.-C., Wu, W.J., Hanson, P. M., Kuo, G., Engle, L. M., Lai, P-Y. (2006). Distribution of 127 edible plant species for antioxidant activities by two assays. J. the Sci. Food Agri. 86(14): 2395-2403. 